\title{
Ambidexterity in micro and small firms: Can competitive intelligence compensate for size constraints?
}

Business Research Quarterly
$1-17$

(C) The Author(s) 202 Article reuse guidelines: sagepub.com/journals-permissions DOI: | $0 . \mid$ | 777/234094442 | I05486 | journals.sagepub.com/home/brq

@SAGE

\author{
Montserrat Boronat-Navarro', Alejandro Escribá-Esteve ${ }^{2}$ iD \\ and Jesús Navarro-Campos ${ }^{3}$
}

\begin{abstract}
Ambidexterity has been linked to firm structures that are typical of organizations with a larger size. However, further research is needed to analyze whether the effect of firm size on ambidexterity is contingent on other aspects. We argue that micro and small firms that have developed some competitive intelligence routines (CIRs) may foster ambidextrous behavior and compensate for the limitations arising from a smaller size and lack of resources. We test our proposal on a sample of 200 firms in the furniture sector. Our results show that CIRs compensate for size constraints in that size is no longer a relevant variable to increase ambidextrous behavior in firms that achieve higher levels in these routines. Our results provide new and important insights into how ambidexterity may be fostered in small firms that lack resource slack or the ability to use separate units to develop knowledge exploration and exploitation activities.
\end{abstract}

JEL CLASSIFICATION: MIO, M2I, O3

\section{Keywords \\ Competitive intelligence, ambidexterity, organizational size, mature industries}

\section{Introduction}

Organizational ambidexterity allows firms to integrate and mobilize different and often contradictory internal structures, activities, or processes (Tushman \& O'Reilly, 1996, p. 1337). Specifically, organizational ambidexterity is defined as the simultaneous achievement of the exploration and exploitation of knowledge (Jansen et al., 2009; Lubatkin et al., 2006; Menguc \& Auh, 2008; Raisch \& Birkinshaw, 2008). Exploration involves experimentation, variation, new knowledge, risk-taking, and searching for new opportunities, whereas exploitation is linked with the refinement, efficiency, and improvement of existing competencies (March, 1991). Both are essential to a firm's competitive advantage because exploitation ensures a firm's current viability and exploration ensures future success (Levinthal \& March, 1993). Therefore, ambidexterity is a fundamental concept for short- and long-term firm performance (O'Reilly \& Tushman, 2013), leading firms to obtain high rates of success (Birkinshaw \& Gupta, 2013; Jansen et al., 2008; Lubatkin et al., 2006; O'Reilly \& Tushman, 2013; Raisch \& Birkinshaw, 2008).
Nevertheless, the complexity of achieving and managing ambidexterity is a challenge for firms, especially for stablished micro and small firms operating in mature and stagnated industries, which have more restrictions on resources than their larger counterparts. Understanding the challenges for micro and small firms is especially relevant because these types of organizations represent the great majority of companies in most national economies. For example, 99.2\% of companies in Spain had less than 50 employees in 2020, and $95.4 \%$ were micro firms (Instituto Nacional de Estadística -Spanish Statistical Institute, 2021).

Firms' ability to develop ambidextrous behavior has been connected to firms' characteristics that require a

\footnotetext{
'University Jaume I, Castello de la Plana, Spain ${ }^{2}$ University of Valencia and Ivie, Valencia, Spain ${ }^{3}$ INNSAI, Valencia, Spain

Corresponding author:

Alejandro Escribá-Esteve, University of Valencia and Ivie, Facultad de Economia, Av. de los Naranjos, s/n, E46022, Valencia, Spain. Email: alejandro.escriba@uv.es
} 
minimum organizational size, such as resource abundance, differentiation of units in their organizational structure, and a broader scope of activities (Lavie et al., 2010; Raisch $\&$ Birkinshaw, 2008). While medium-sized and large firms may enjoy of the advantages of structural differentiation and specialization, small and micro firms often lack necessary resources and have difficulty organizing their activities in such a way that some units focus on exploration and others focus on exploitation.

Given these potential constraints for micro and small firms, in this study, we analyze the influence of other organizational routines and orientations that may depend less on a company's size and help small firms increase their ambidexterity. Specifically, we argue that smaller firms that become aware of the importance of being ambidextrous will organize their activities and devote effort and creativity to attain it. In this sense, the adoption of competitive intelligence routines (CIRs) can help firms scan the environment and realize its complexity and uncertainty and the necessity to adopt both a short- and long-term perspective to succeed.

Usually, medium-sized and large firms have more resources and units that implement competitive intelligence systems to scan the environment and, thus, appreciate the importance of achieving ambidexterity. However, we propose that when firms adopt CIRs, the influence of size on ambidexterity is reduced. CIRs help organizations, regardless of their size, realize the importance of devoting resources to exploration and exploitation.

This study analyzes the moderating effect of CIRs on the relationship between organizational size and ambidexterity, contributing to the call for further research on ambidexterity in small firms (Prajogo et al., 2013; Soto-Acosta et al., 2018). Frequently, research on small and mediumsized enterprises (SMEs) considers this type of firms as a homogeneous set compared with large firms. However, SMEs are highly heterogeneous in terms of organizational practices, routines, structures, and decision-making processes (Ghobadian \& Gallear, 1997; McAdam et al., 2010; Prajogo et al., 2013). In this sense, our work studies the effect of adopting a specific type of organizational routine that may moderate the effect of differences in size within the SME category. Thus, we attempt to go deeper into understanding the mechanisms that trigger ambidextrous behaviors in small and micro firms (Prajogo et al., 2013).

Specifically, we analyze whether the presence of CIRs, in terms of habits and tendencies to collect information on external conditions and trends, moderates the differences in the level of ambidexterity among firms of different sizes. Our study argues that even if firms of diverse sizes maintain differences regarding resource availability and flexibility, the systematic knowledge of external trends, opportunities, and threats creates strong awareness about the importance of being ambidextrous, prompting firms to pursue ambidexterity.
Therefore, we respond to the call to advance the analysis of contingencies in the study of ambidexterity (Fourné et al., 2019) by investigating the unexplored contingent influence of CIRs on the relationship between size and ambidexterity. We also investigate competitive intelligence, following Lindgreen and Di Benedetto's (2018) urging, as it represents an important topic for many marketing scholars who consider gathering external information as a component of market orientation (Hunt \& Madhavaram, 2020). Furthermore, we contribute to the analysis of CIR in the Spanish context, where most of the companies operate in mature and fragmented industries. We test our hypothesis in a sample of furniture companies, a highly fragmented, mature and nonmunificent industry, where the challenge for the majority of companies to be ambidextrous is extremely complex. We introduce a new perspective to face these challenges, considering the use of CIR as way to moderate the size constraints that characterize firms in this type of industries. Meaningful studies that include samples of Spanish companies have focused on the analysis of the model, methods, or types of activities used for CI (e.g., Cantonnet et al., 2015; Muñoz-Cañavate \& Alves-Albero, 2017), or on the antecedent variables for the adoption and usage of CI, both external and internal to the firm (e.g., Cantonnet et al., 2015; Casado Salguero et al., 2019). Placer-Maruri et al. (2016), Navarro et al. (2008), or Navarro (2012) showed that SMEs that use CI or that participate in institutional competitive intelligence programs show better adaptation capacity to the environment, and higher innovation capacity, also supporting value creation. We contribute to this line of research by proposing a different perspective of the CIR's positive importance.

Our results provide important insights for smaller firms because they show that CIRs may compensate for size constraints in the pursuit of ambidexterity. Our results show that when firms maintain a longer and stronger commitment to develop and collect competitive intelligence data, size is no longer a variable that determines the level of ambidexterity.

In the next sections, we introduce the ambidexterity concept and explain the influence that firm size may have on ambidexterity. Then, we address the moderating effect of CIRs. In the third section, we explain the sample selection and the methodology. The fourth section presents our results, which are then discussed in the fifth section. We present the conclusions in the last section.

\section{Theoretical framework and hypotheses development}

\section{Ambidexterity}

From an organizational learning perspective, March (1991) was the first to bring the concepts of exploration and exploitation into the management literature. Successful 
organizations need to exploit existing knowledge to ensure their current viability and explore new possibilities that might provide future viability (Levinthal \& March, 1993; Tushman \& O'Reilly, 1996). Simultaneously obtaining high levels of both activities is understood as organizational ambidexterity (Gibson \& Birkinshaw, 2004; He \& Wong, 2004). Exploring without exploitation could lead the firm into the "failure trap" because exploration has high variability in its results and could impede gaining returns from knowledge, whereas exploitation without exploration leads to the "competence or success trap," with firms engaging in activities that provide immediate success but are not adequate for future environments and their changing demands (Ahuja \& Lampert, 2001; Leonard-Barton, 1992). To avoid these traps, firms must find a way to become ambidextrous.

However, developing ambidextrous behavior is challenging for most companies because exploration and exploitation require different, frequently clashing processes, strategies, and capabilities (Gibson \& Birkinshaw, 2004; He \& Wong, 2004; Tushman \& O’Reilly, 1996). Each arises from distinct knowledge processing capabilities (Floyd \& Lane, 2000) that may compete for a firm's scarce resources. They are also complementary because exploring new capabilities often requires the exploitation of existing ones when enhancing the previous knowledge base (Jansen et al., 2009; Li \& Huang, 2012). Previous literature has defined ambidexterity as a firm's dynamic ability to simultaneously pursue exploration and exploration (Cao et al., 2009; Gibson \& Birkinshaw, 2004; He \& Wong, 2004; Jansen et al., 2006; Lubatkin et al., 2006; O'Reilly \& Tushman, 2004; Tushman \& O'Reilly, 1996).

\section{Antecedents of ambidexterity: the effect of firm size}

Achieving ambidexterity means that a firm simultaneously attains a good level of knowledge exploration and exploitation. Ambidexterity implies considerable complexity (Voss \& Voss, 2013) that requires different sets of resources and capabilities to resolve (Cao et al., 2009; March, 1991). Although exploration and exploitation may be mutually reinforcing (Gibson \& Birkinshaw, 2004; Raisch et al., 2009), they inevitably generate organizational tensions (Lubatkin et al., 2006) because they emerge from different knowledge processes and, hence, require different activities, capabilities, and strategies (Benner \& Tushman, 2003; Floyd \& Lane, 2000; Lubatkin et al., 2006; McGrath, 2001; Siggelkow \& Levinthal, 2003).

The literature has analyzed different ways of simultaneously achieving exploration and exploitation and has found two main methods: structural (Benner \& Tushman, 2003) and contextual ambidexterity (Gibson \& Birkinshaw, 2004). The former implies creating different subunits focused on either exploration or exploitation (Duncan,
1976; Jansen et al., 2009; Lavie et al., 2010). While exploitation units can have routinized tasks, the explorationdevoted unit must be creative; for example, centralization and formalization should be downplayed and a culture that promotes creativity should be fostered. Structural ambidexterity also requires the complex task of firm-level integration of different subunits that are physically and culturally separated to attain ambidexterity (Siggelkow \& Rivkin, 2006) successfully. Alternatively, contextual ambidexterity implies creating a context that allows firms to achieve ambidexterity without separating organizational units devoted to different objectives (Gibson \& Birkinshaw, 2004). It is achieved using higher-order processes and systems that allow managers and employees to devote their time to conflicting demands according to their judgments (Gibson \& Birkinshaw, 2004). This approach also implies considerable complexity because it requires the development of intricate processes and management systems (Gibson \& Birkinshaw, 2004; Voss \& Voss, 2013).

Different internal and external factors have been identified as potential antecedents of ambidexterity in terms of their influence on creating the right context or structures to foster the simultaneous execution of activities to explore new or exploit existing knowledge. Regarding internal factors, previous research has highlighted the importance of having the absorptive capacity to capture and take profits from new knowledge, the slack of resources to be deployed, the company culture, or the availability of an organizational structure that facilitates the combination of both knowledge exploration and exploitation (Lavie et al., 2010; Raisch \& Birkinshaw, 2008).

No consensus exists about the role of size as an antecedent of ambidexterity. However, a significant number of researchers (e.g., Atuahene-Gima, 2005; Lubatkin et al., 2006; Raisch \& Birkinshaw, 2008; Voss \& Voss, 2013) suggest that larger firms, that is, those that enjoy of a minimum structure and amount of resources, are in a better position to support the conditions that may allow for the simultaneous pursuit of exploration and exploitation. They argue that larger firms have more resources to invest and dedicate to different activities (slack resources) and have more chances to have employees with different specializations and to implement differentiated units in their organizational structure that may focus their attention (differentiation and separation of organizational units) on either exploiting the current knowledge that the firm already has or exploring new development possibilities.

They also believe that resource-abundant firms may be in a better position to support contextual ambidexterity by devoting efforts to both processes (exploration and exploitation) and finding the synergistic effect between them (He $\&$ Wong, 2004). These firms can also dedicate significant resources to foster creativity and maintain their usual knowledge exploitation processes (Damanpour, 1991). A larger size usually implies refined administrative processes 
that may help manage and integrate contradictory processes (Chang \& Hughes, 2012; Lubatkin et al., 2006).

Furthermore, the higher quantity and variety of resources in larger companies are also indicative of broad diversity in the knowledge base, ideas, and systems that create opportunities for exploring new uses of existing knowledge (Revilla \& Rodriguez-Prado, 2018; Wuyts et al., 2004) and for implementing the required and complex processes to achieve such opportunities (Cao et al., 2009; Voss \& Voss, 2013). In this sense, a greater variety of cognitive styles, expertise, and ideas provides the necessary surroundings for pursuing ambidexterity (Revilla \& Rodriguez-Prado, 2018).

In addition, abundant resources can act as a shock absorber in the event of risks inherently associated with ambidextrous behaviors and, in this sense, firms with larger resources can mitigate or avoid risks and negative shocks, reducing possible problems in ambidexterity demands (Bourgeois, 1981; Cao et al., 2009). Slack financial resources allow firms to assign supplementary resources to exploration and exploitation activities (Jansen et al., 2012; Sirmon et al., 2007).

In contrast, smaller firms have fewer chances to create separate units and lack the necessary resources to cope with the complexity of integrating separated units into a single functional area (Siggelkow \& Rivkin, 2006; Voss \& Voss, 2013). Small firms need to rely more on antecedents related to the flexibility of their organizational structure and culture and their managers' abilities, and other factors that can be less size-dependent (Lubatkin et al., 2006). In this sense, managerial and strategic orientations may be relevant. For example, Menguc and Auh (2008) show that the relationship between size and ambidexterity is positive for prospectors but negative for defenders, indicating that there may be an effect of the firms' attitudes about how they face their competitive challenges.

Therefore, although micro and small firms' limited resources do not impede their ambidexterity, they impose an additional challenge to achieving ambidexterity (Andriopoulos \& Lewis, 2009; Voss \& Voss, 2013). This does not mean that smaller firms cannot achieve ambidexterity. They can rely on other advantages, such as flexibility to manage changes (Alcalde-Heras et al., 2019; Veugelers, 1997) and reduced inertia when reacting (Fourné et al., 2019). However, having enough resources implies that firms can better support different processes, such as those underlying exploration and exploitation (Cao et al., 2009). Consequently, achieving ambidexterity could be more pressing for smaller firms than for their larger counterparts (Soto-Acosta et al., 2018; Voss \& Voss, 2013). In this sense, the size of an organization can be considered a facilitator of ambidexterity.

According to our previous argumentation, based on the idea that a large enough organizational size provides better conditions that support the ambidexterity context, we propose the following hypothesis:
Hypothesis 1: A larger organizational size increases the likelihood of achieving higher levels of ambidexterity.

\section{Moderating role of CIRs}

Although a larger firm size may help create the structures and implement the integrating processes identified as antecedents of ambidexterity, smaller firms may be as ambidextrous as larger firms by using their idiosyncrasies to foster ambidextrous behaviors. Fourné et al. (2019) highlight some characteristics of smaller firms that may help them pursue ambidexterity. In general, smaller firms are more flexible than larger firms and can react more easily to any changes or trends in the environment. In addition, small companies' managers may be closer to market trends and their simpler structures may be useful to create a context in which communication and information are fluent among different company members; creativity may be easier to identify and apply to solve specific problems.

Firms, independently of their size, that adopt a more proactive behavior toward knowledge exploration usually pay more attention to the evolution of environmental trends and their main competitors' competitive actions and innovations. Knowledge about current and future environmental changes is considered crucial for organizational adaptation, thus helping with strategic planning and change (Hambrick, 1982). For example, Zollo and Winter (2002) adopt the dynamic capabilities view and organizational learning approach to recognize knowledge about the external environment as a critical stimulus in their knowledge evolution cycle, which includes steps that shape exploration and exploitation. In fact, the micro-foundations of dynamic capabilities explicitly include sensing (Teece, 2007) as a major component. Sensing requires the "ability to recognize, sense, and shape developments" (Teece, 2007, p. 1323) and necessitates access to external information. Marketing scholars have also outlined the need to monitor firms' external factors (e.g., Hunt \& Madhavaram, 2020). In addition, Erickson and Rothberg (2009) state that competitive intelligence (together with knowledge management) is a crucial strategic factor.

Specifically, the literature on ambidexterity acknowledges that awareness of challenges and conditions in the external environment is key to maintaining alignment and efficiency in the management of today's business demands when adapting to changes and is crucial in preparing the company to effectively respond to future trends (Raisch \& Birkinshaw, 2008, p. 375).

Knowing changes and trends outside firm boundaries is essential to achieving a competitive advantage (Haase \& Franco, 2011; Olsen \& Sallis, 2006; Tang, 2016). It also allows for a better understanding of market developments and opens up possibilities of introducing new knowledge and ideas into the organization (Paliokaite \& Pacesa, 2015; Rohrbeck \& Gemunden, 2011), recognizing new technologies and markets (Daft et al., 1988), and entering new 
domains (Danneels, 2008). Managers' decisions are affected by how they perceive environmental dynamism (Alexiev et al., 2020; Boyd \& Fulk, 1996). Knowing external trends facilitates the change from a reactive orientation toward proactive behaviors (Pfeffer \& Salancik, 1978; Yasai-Ardekani \& Nystrom, 1996).

Here, we focus on the idea that a deep acquaintance with external trends regarding customers and competitors acts as a trigger for managers to think about their organization's current behavior and the need to invest in new capabilities (Atuahene-Gima, 2005; Huff et al., 1992). When managers perceive environmental uncertainty, they can design actions to cope with these ambiguities (Brown \& Eisenhardt, 1997; Zhang \& Han, 2019). This knowledge provides the firm with the stimulus to carry out new developments (Morgan \& Berthon, 2008; Ramachandran et al., 2019). The awareness of external trends helps firms question their current practices (Atuahene-Gima, 2005; Barnett et al., 1994). If firms are unaware of the importance of gathering external information, they could enter into temporal and spatial myopia concerning their current strategies, technology, and processes (Ridge et al., 2014).

Specifically, the awareness-motivation-capability perspective (Chen, 1996), derived from social cognition theory, establishes an awareness of external facts as one of the three pivotal motors driving a firm's decision to act (Chen, 1996; Chen et al., 2007). Although we do not aim to specifically test this framework, understanding the importance of awareness is helpful. Some authors within the framework of the awareness-motivation-capability perspective measure awareness as environmental scanning (e.g., Shu et al., 2020). We consider that firms must be aware of the importance of the attainment of awareness to be motivated to invest their efforts in achieving ambidextrous behavior. Awareness precedes the motivation and ability to act (Chen et al., 2007).

Knowing market developments, opportunities, and threats (Hambrick, 1982; Wood, 2001) requires that firms develop specific routines to analyze the external environment. Trends, opportunities, and future constraints in the environment can be difficult to diagnose (Haase \& Franco, 2011). However, firms should pay frequent and active attention to competitive intelligence and environmental scanning routines to recognize opportunities and anticipate threats (Helfat \& Peteraf, 2015; Peteraf \& Bergen, 2003; Teece, 2007). Indeed, Daft et al. (1988) found that highperforming firms scanned more broadly and frequently than low-performing firms. Other researchers found similar results in different environments (Priem et al., 1995).

Aguilar (1967) defines environmental scanning as "the acquisition and use of information about events, trends, and relationships in an organization's external environment, the knowledge of which would assist management in planning the organization's future course of action" (p. 1). Specifically, CIRs are linked with the concept of environmental scanning (de Almeida et al., 2016) and allow firms to collect and interpret knowledge about their competitive environment (Bernhardt, 1994; de Almeida et al., 2016).

Although environmental scanning through CIRs does not guarantee an organization's capability to adapt to changing conditions, it represents a necessary step to obtain and understand external information about trends and changes beyond organizational boundaries (Qiu, 2008).

Research on external scanning has mostly focused on large companies (Haase \& Franco, 2011; Liao et al., 2008; Smith et al., 2010) because SMEs have greater difficulty developing the infrastructure to gather environmental information (Matthews \& Scott, 1995; Zinkhan \& Gelb, 1985 ) and cover all available sources (Haase \& Franco, 2011). Liao et al. (2008) state the reasons for small firms having lower levels of scanning systems as follows: lack of formal structures to collect and process information, fewer external contacts, difficulty in accessing management information systems, lack of influence on external events, fewer managers who can dedicate time to scanning activities and lack of resources for information searches (Liao et al., 2008). Along the same line, awareness has been measured in some studies from the awareness-motivation-capability perspective (Chen, 1996) using the scale of organizational operations as a proxy, given that knowledge about external information is considered to be greater in large firms than in small firms (Chen et al., 2007).

Therefore, the disadvantages for smaller firms from their lack of resources also apply to their ability to develop competitive intelligence activities. For SMEs, and specially for micro and small firms, it is usually difficult to invest in advanced computing systems (Rialti et al., 2019). Whereas large firms have devoted systems to support their strategy development, small firms incorporating such schemes are scarce (Smith et al., 2010). Furthermore, Smith et al. (2010) note that small firms, because of their lack of structure and resources, typically show greater resistance toward integrating CIRs in their strategic development and decision-making processes. Nevertheless, smaller firms have other opportunities to integrate CIRs. Evidence exists of programs sponsored by governments, such as in the case of France (Smith et al., 2010; Smith \& Kossou, 2008), Quebec (Bergeron, 2000), and Spain (Navarro et al., 2008), which support the creation of competitive intelligence centers to provide such systems to SMEs. These collaborative approaches reduce costs relative to the development of competitive intelligence systems in isolation and help acquire flows, trends, and information about others' experiences (Barron et al., 2015). As small firms use and profit from these programs, they develop new routines to incorporate external information about the competitive environment in their decisionmaking processes. Once small firms become aware of the 
importance and utility of having access to this information, they become more proactive and committed to maintaining such CIRs, even if the programs no longer exist.

Being aware of the positive aspects of having more and better information about external factors that affect companies' current and future prospects increases firms' dedication to building and maintaining environmental scanning routines, collecting external information, and considering broader and more objective perspectives in their decisionmaking processes.

We propose that firms that have developed CIRs are conscious of the importance of combining exploitation and exploration behaviors and will increase their efforts to become more ambidextrous. Small and micro firms may have difficulty integrating CIRs; however, when they have the opportunity to develop these scanning routines, either alone or through their participation in CI institutional programs, they can use their agility and determination to compensate for their constraints in developing ambidexterity relative to large firms. That is, in the presence of CIRs, the impact of size on ambidexterity is reduced. However, when CIRs do not exist or are weak, small and micro firms face a situation that seriously obstructs ambidexterity because it combines a lack of awareness of external trends and changes that require a long-term perspective and high levels of exploration with lack of resources and structures that facilitate organizational ambidexterity. In this context, most small firms are typically focused on their current practices without internalizing the urgencies about threats, opportunities, and trends in the external environment.

In this sense, awareness of external trends helps firms question their current practices (Atuahene-Gima, 2005; Barnett et al., 1994). Regardless of the firm's size, the motivation to change is triggered when firms acknowledge that environmental changes and trends require new ways of acting. When managers perceive environmental uncertainty and understand how this may compel changes in the current business model, they can design actions to manage these ambiguities (Brown \& Eisenhardt, 1997; Zhang \& Han, 2019). In this sense, Posch and Garaus (2019) test the effects of the level of perceived environmental uncertainty on the relationships among organizational variables, such as strategic planning, leaders' innovation orientation, and ambidexterity. Thus, when firms deeply understand external trends regarding customers and competitors, they start to think about their current behavior and the need to invest in new capabilities (Atuahene-Gima, 2005; Huff et al., 1992). In the presence of CIR, size loses importance as an antecedent of ambidexterity because firms can realize the importance of investing in exploration and exploitation. Smaller firms can put their advantages to achieve ambidexterity and larger firms can use their specificities to invest in ambidexterity. Firms without routines that allow them to know and understand these external trends have more difficulties exploring and exploiting their capabilities (Atuahene-Gima, 2005).
However, to perceive these external changes and uncertainties, firms need to systematically, proactively, and frequently pay attention to the trends. Having CIRs makes firms of different sizes comparable in terms of their knowledge about future challenges and their importance to become more ambidextrous. In this sense, CIRs can balance the orientation toward ambidexterity, both at small and large firms, reducing the positive effect of size on ambidexterity. Other advantages in terms of large firms' resources and structures can still be present, but the importance of achieving ambidexterity for current and future firm competitiveness is more evident for firms that understand external trends regardless of their size. Knowing external trends is necessary to realize the importance of developing new capabilities and exploiting current ones (Atuahene-Gima, 2005). Therefore, firms understanding environmental trends should be more inclined to carry out exploitation to maintain and improve their current activities and explore new ways of managing environmental uncertainties.

Although size is proposed to effect ambidexterity positively, the presence of CIRs weakens the differences between companies of varying sizes. Smaller firms have fewer resources than their larger counterparts; however, when they consistently obtain information from competitive intelligence systems, they have their own way and alternatives to responding to environmental pressures. Consequently, the impact of size is reduced, making firms with different sizes more equivalent in terms of ambidexterity.

Thus, we propose the following hypothesis:

Hypothesis 2: The positive effect of size on ambidexterity will be weaker when firms demonstrate a certain level of CIRs (e.g., consistently participating in sectorial competitive intelligence systems).

Figure 1 represents the proposed model.

\section{Methodology}

\section{Data and sample}

Our study analyzes whether larger firms' advantages to foster ambidextrous behaviors are not as relevant when firms use CIRs in their strategic decision-making processes. We assume that the presence of CIR will reduce the effect of firm size. Smaller firms, that is, micro and small companies, often lack slack resources and face difficulties having separate structures to conduct simultaneous exploration and exploitation activities but can leverage their CIRs to better understand the market trends and changes and incorporate this knowledge into their decision-making processes.

The sample used to test these hypotheses is obtained from a panel of companies participating in a competitive 


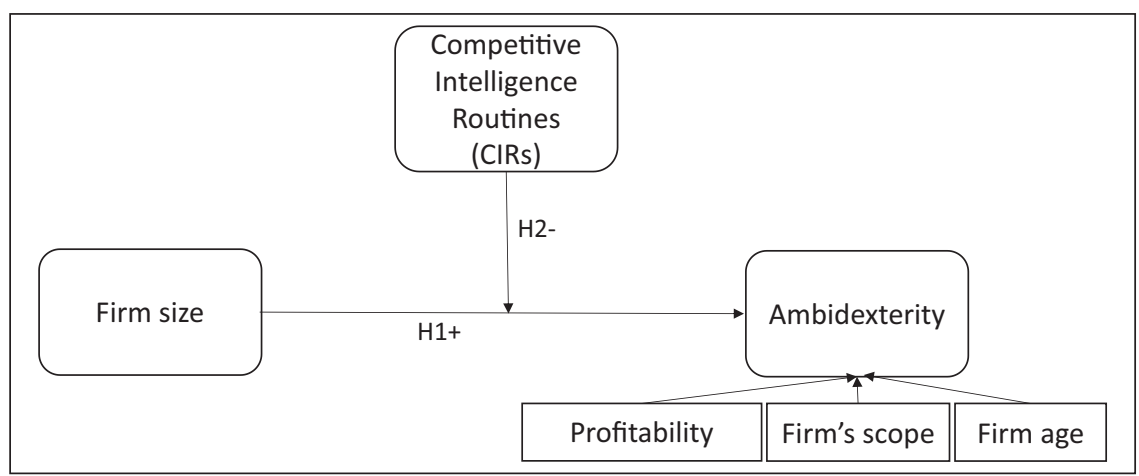

Figure I. Proposed model.

intelligence system for Spain's furniture industry (Spanish Observatory of the Furniture Market). This competitive intelligence system was developed by a technological institute that focuses its activities on the metalworking, furniture, wood, packaging, and related industries (www. aidimme.es). Most companies belonging to the furniture industry in Spain are SMEs and frequently have serious limitations when developing their own environmental scanning and competitive intelligence systems. The technological institute developed the Spanish Furniture Market Observatory (see Navarro et al., 2008, for additional information about its characteristics) to collect information about suppliers, competitors, retailers' strategies and initiatives, market trends, competitors' performance, and consumer behavior. The sample includes companies from industries comprised of furniture manufacturers, competitors, and retailers. ${ }^{1}$

Companies could participate voluntarily in the observatory and contributed to the competitive intelligence system both economically and by providing information. An annual fee was required to obtain the information and reports (free of charge for companies regularly providing information) and to access events and presentations of market trends. In addition, participants received four questionnaires every year in which they were asked to provide information about their strategic initiatives, innovations, evolution of sales and markets, and so on. We assume that the longer a company participated in the observatory dedicating time, resources, and money, the higher the probability that it found that receiving reports, information, and advice from the competitive intelligence system was valuable. In this sense, we assume that firms that were part of the observatory for an extended period probably found the system's information useful and developed their own CIR to apply the obtained information in their decision-making processes.

We collect information on the duration and proactivity of companies' participation in the observatory for 51 quarters (from 1999 to 2011). Observations with missing data for any of the variables are excluded. Questions about ambidexterity are included in the panel questionnaires corresponding to the fourth quarter of 2011 and the first and second quarters of 2012. We obtain a final sample of 200 companies with complete information (59\% of the original database's possible observations during the selected period). In the final sample, a percentage of $30 \%$ are micro firms with less than 10 employees, $46 \%$ are small firms with a number of employees between 10 and $49,21 \%$ are medium-sized firms that have between 50 and 249 employees, and 3\% are large firms with 250 employees or more. This distribution is similar to the characteristics of the industry. Larger firms (i.e., medium-sized and large) are slightly overrepresented, but their presence is necessary to evaluate the potential impact of size in ambidexterity. The mean turnover in the sample reaches the level of $€ 17$ million, and the largest company has 6,641 employees with an annual turnover of almost $€ 2$ billion. The sample includes companies operating in different subsectors of the furniture value system, where $71.5 \%$ of them are furniture manufacturers, $16 \%$ are furniture distributors or retailers, and $12.5 \%$ are suppliers of furniture materials and components.

The duration and proactivity of companies' participation are observed as the number of quarters in which a company participated in providing data to the observatory from the first participation to the fourth quarter of 2011. We also compute whether the companies provided answers to the different questionnaires before the established deadline or after the first reminder to submit the answers. Long permanence and proactive answers reflect the commitment and interest of companies in the value provided by the competitive intelligence system.

\section{Measurement}

Dependent variable: ambidexterity. To create the ambidexterity variable, we follow a procedure similar to the one used in previous studies (e.g., Cao et al., 2009; Gibson \& Birkinshaw, 2004; He \& Wong, 2004; Li \& Huang, 2012) that consists of two steps. In the first step, exploration and exploitation scales are validated. In the second step, a multiplicative term between exploration and exploitation is calculated to measure ambidexterity. 
Table I. Results of exploratory factor analysis.

\begin{tabular}{ll}
\hline Factors and items & Loadings \\
\cline { 2 - 2 } & Factor I \\
\hline Exploration & $0.74 \mathrm{I}$ \\
We invent new products and services. & 0.722 \\
We experiment with new products and services in our local market. & $0.76 \mathrm{I}$ \\
We commercialize products and services that are completely new to our firm. & \\
Exploitation & 0.822 \\
We improve our efficiency in the provision of products and services. & 0.750 \\
Our unit expands services for existing clients. & 0.783 \\
Lowering costs of internal processes is an important objective. & \\
\hline
\end{tabular}

First, we measure the exploration and exploitation components following the scales proposed by Jansen et al. (2006). These scales have been widely used in the literature in different organizational contexts and their applicability shown in different industries and firm sizes (e.g., Hughes et al., 2020; Jansen et al., 2009; Kammerlander et al., 2020; Li \& Huang, 2012), including studies about SMEs (e.g., Alexiev et al., 2010; Jiménez-Jiménez et al., 2019; Limaj \& Bernroider, 2019; Soto-Acosta et al., 2018). Following previous research (e.g., Alexiev et al., 2010; Jiménez-Jiménez et al., 2019), we adapt the original scale (addressed to business units from a large European financial service firm) to the SME context. Respondents are asked to assess their firm's orientation during the previous 3 years using a 7-point scale ranging from strongly disagree (1) to strongly agree (7).

The original proposal from Jansen et al. (2006) was composed of seven items for exploration and seven for exploitation. The validity of these scales for our study is tested by applying several statistical analyses. First, we perform an exploratory factor analysis through a principal components analysis with a varimax rotation, as suggested by Kaiser (Hair et al., 2006). See Table 1 for the factor loadings of the final items. Some of the original scale items are deleted because of low factor loadings $(<0.6)$ or high cross loadings $(>0.39)$. The explained variance of the two final extracted factors (near the cutoff point of $50 \%$ ) is $46.14 \%$, with the first factor explaining $25.21 \%$ of the variance. The Kaiser-Meyer-Olkin measure for sampling adequacy is 0.779 , and Bartlett's test of sphericity is $602.73(p<.001)$.

Then, we perform a confirmatory factor analysis. The model fits the data well according to the goodness-of-fit indices, which show appropriate values (Bentler and Bonett's Normed Fit Index [BBNFI] =0.949; Bentler and Bonett's Non Normed Fit Index [BBNNFI] =0.944; comparative fit index $[\mathrm{CFI}]=0.978$; incremental fit index $[\mathrm{IFI}]=0.979$; root mean square error of approximation $[\mathrm{RMSEA}]=0.075$; standardized root mean square residual $[\mathrm{SRMR}]=0.067)$. All of the loadings are significant $(p<.05)$ on the intended factors, thus ensuring convergent validity (Anderson \& Gerbing, 1988).
The resulting scales for exploration and exploitation reach Cronbach's alpha values higher than the cutoff of .70 ( $\alpha$ of exploration $=.768 ; \alpha$ of exploitation $=.783$ ), thus confirming scale reliability. The composite reliability (CR) also exceeds the recommended value of .70 (CR of exploration $=.773$; $\mathrm{CR}$ of exploitation $=.787$ ) (Anderson \& Gerbing, 1988). In addition, the average variances extracted (AVE) are higher than the 0.5 cutoff (AVE exploration $=0.535$; AVE exploitation $=0.553$ ). Furthermore, the square root of the AVE of each construct exceeds the correlation between both constructs $(r=.263)$, which is also a test for discriminant validity (Fornell \& Larcker, 1981). Therefore, both constructs show adequate unidimensionality, reliability, and convergent and discriminant validity (Fornell \& Larcker, 1981).

The resulting three-item scale for exploration measures the extent to which the firm departs from existing knowledge in the innovation of products and services that are completely new or new to the market or to the firm. The three-item exploitation scale captures the degree to which a firm relies on existing knowledge to improve its products and services and their efficiency.

Following the idea that exploration and exploitation are nonsubstitutable and interdependent, we create an ambidexterity variable with a multiplicative term between exploration and exploitation in line with several studies (Gibson \& Birkinshaw, 2004; He \& Wong, 2004; Hill \& Birkinshaw, 2014; Jansen et al., 2008, 2012; Koryak et al., 2018; Li \& Huang, 2012; Menguc \& Auh, 2008; Yang et al., 2014).

Independent and moderating variables. Our independent variable is the size of the firm measured by number of employees. Following Cao et al. (2009) and AtuaheneGima (2005), among others, to ensure normal distribution, we use a logarithmic measure to proxy firms' size because this variable's distribution is skewed.

Regarding the measure of CIRs, we assume that small and micro firms that have incorporated CIRs in their strategic decision-making processes will show a higher commitment to feeding a sectorial competitive intelligence 
system. They will dedicate resources, time, and effort to supply information; attend sessions to collect feedback, sectorial information, and aggregated data; debate with experts about market trends; and pay attention to competitors', suppliers', and retailers' actions and reactions. We proxy the existence of CIR through an analysis of how long and how proactively a company participated in the Spanish Observatory of the Furniture Market. Companies participating in the observatory committed to answering four long questionnaires each year. They also participated in several events and attended frequent meetings.

Our measure of their involvement in the competitive intelligence system captures the percentage of spontaneous answers (before receiving any reminder) that a company provided to the quarterly surveys since they started their formal association with the observatory. We assume that the higher a company's commitment to the system, the higher the value they obtain from the observatory and the higher the likelihood that they incorporate the competitive intelligence information into their decision-making routines. Other studies use subjective approaches to assess the existence of CIR, measuring competitive intelligence as the formality and use of scanning routines. For example, in a study in the Spanish hotel industry, Casado Salguero et al. (2019) measure competitive intelligence effort as the sources of information that hotels use, such as specialized press, networking, and big data. Other authors include the use of SME associations (e.g., Barron et al., 2015). Among studies that objectively measure competitive intelligence, Erickson and Rothberg (2009) use the number of members of a competitive intelligence association to reflect the size of the competitive intelligence operations in a sector. In our proposed measure, the periods of participation, together with their proactive character, reflect the degree of a firm's commitment to information searches about the environment and its awareness of the importance of this information in its decision-making processes. We consider the period of participation a good proxy for CIRs because, without the development of CIRs and their integration in firms' strategic thinking, it would be unreasonable for small firms to dedicate financial and nonfinancial resources to proactively participate for many years in the information-seeking and reporting processes in this panel of sectorial competitive intelligence.

Control variables. Following previous studies on ambidexterity (e.g., Bauer \& Leker, 2013; Lubatkin et al., 2006), we control for the firm's profitability because it represents the capability to invest in different activities. To measure this variable, we extract data from the SABI database (Sistema de Análisis de Balances Ibéricos, in Spanish), developed by INFORMA D\&B and Bureau Van Dijk. We construct the measure as the ratio of earnings before interest, taxes, depreciation, and amortization to operating revenue in the last available year (e.g., Lerner, 2006; Neirotti \& Paolucci, 2011).
The firm's scope is also introduced as a control variable because it could influence ambidexterity (Raisch \& Birkinshaw, 2008). This indicator measures the number of activities that differ from the main activity under which the company operates. This variable takes the value of 0 if the firm only operates under its main activity, 1 if the firm has one more activity than the main one, and 2 if the firm has two or more activities in addition to its main activity. Of the 200 companies in our sample, 189 operated exclusively in one business. Only seven companies (two distributors, three manufacturers, and two suppliers) had an additional business in their corporate portfolio, and four companies had two additional businesses. As the level of diversification depends not only on the number of businesses but also on the degree of relatedness between the industries in the corporate portfolio (Robins \& Wiersema, 2003), we double $(\times 2)$ the weight of unrelated businesses regarding related ones. Only one company had an unrelated business (hospitality) in our sample.

Firm age is calculated as the logarithm of the difference between the year of observation of our dependent variable (2011) and the year the firm was founded. Firm age is introduced as a control variable, following previous studies on ambidexterity (e.g., Jansen et al., 2012) because age has been associated with inertia (Tushman \& Romanelli, 1985) and rigidity (Autio et al., 2000).

\section{Methods}

We use a hierarchical regression to test the hypotheses and first introduce the control variables; in the next step, the main variables are introduced, followed by the moderating variable (Cohen \& Cohen, 1983) through an interaction term. Before creating the interaction, the variables are mean centered to reduce possible multicollinearity problems (Aiken \& West, 1991). We also plot the independent variable on the dependent variable in high, medium, and low moderating variable values to facilitate the interpretation of results. Then, we apply the Johnson-Neyman technique to specifically evaluate the moderating effect (Preacher et al., 2007), analyzing regions in which the coefficient of the independent variable is significant, conditional on the different values of the moderating variable.

\section{Results}

Table 2 shows the means, standard deviations, and correlations among the variables of this study. The correlation levels are lower than .4 in all cases (see Table 1), confirming the variables' discriminant validity.

The variance inflation factors range between 1.002 and 1.269 , much lower than the recommended value of 10 ; therefore, multicollinearity is unlikely to be a problem (Belseley et al., 1980).

To test the hypotheses, we run a series of hierarchical regression models. Model 1 in Table 3 includes the control 
Table 2. Descriptive statistics and correlations.

\begin{tabular}{|c|c|c|c|c|c|c|c|}
\hline Variable & M & $S D$ & Profitability & Firm age & Firm scope & $\begin{array}{l}\text { Competitive } \\
\text { intelligence routines }\end{array}$ & Firm size \\
\hline Profitability & -0.067 & 0.308 & & & & & \\
\hline Firm age (log.) & 1.377 & 0.209 & .052 & & & & \\
\hline Firm scope & 0.075 & 0.332 & -.145 & .034 & & & \\
\hline Competitive intelligence routines & 30.879 & 24.655 & -.061 & .070 & .090 & & \\
\hline Firm size $(\log )$. & 1.363 & 0.601 & .142 & .392 & .041 & .254 & \\
\hline Ambidexterity & 18.518 & 10.284 & .175 & -.177 & .198 & -.028 & .081 \\
\hline
\end{tabular}

Note: $N=200$. Correlations higher than . I40 are statistically significant at $p<.05$ (bilateral).

Table 3. Results of regression analysis.

\begin{tabular}{|c|c|c|c|c|}
\hline \multirow[t]{2}{*}{ Variable } & \multicolumn{2}{|l|}{ Model I } & \multicolumn{2}{|l|}{ Model 2} \\
\hline & $\beta$ & $t$ & $\beta$ & $t$ \\
\hline Profitability & $0.172 *$ & 1.937 & $0.183 * *$ & 2.075 \\
\hline Firm age & $-0.262 * * *$ & -2.917 & $-0.244 * * *$ & -2.737 \\
\hline Firm scope & $0.266 * * *$ & 3.033 & 0.27 I *** & 3.130 \\
\hline Firm size & $0.165^{*}$ & 1.713 & $0.182 *$ & 1.916 \\
\hline CIRs & -0.106 & -1.140 & -0.091 & -0.985 \\
\hline Firm Size $\times$ CIRs & & & $-0.175^{* *}$ & -2.021 \\
\hline$R^{2}$ & .157 & & .186 & \\
\hline Adjusted $R^{2}$ & .120 & & .143 & \\
\hline$R^{2}$ change & .009 & & .023 & \\
\hline$F$ value & $4.286 * * *$ & & $4.348 * * *$ & \\
\hline F change & 0.024 & & $0.029 * *$ & \\
\hline
\end{tabular}

Note: $\mathrm{CIRs}=$ competitive intelligence routines. Dependent variable $=$ Ambidexterity.

$*_{p}<.1 . *_{p}<.05$. $* * * p<.0 \mathrm{I}$.

variables and the direct effects of the independent and moderating variables. In this model, the coefficient of the size variable is positive and significant $(\beta=0.165 ; p<.10)$, as it was expected in our Hypothesis 1.

The interaction term between the size and CIR variables is introduced in Model 2 and presents a significant negative coefficient $(\beta=-0.175, p<.05)$. The interaction effect exists if the coefficient is significant and if it involves a significant effect to the previous model in which only the control variables and the main effects are included (Cohen \& Cohen, 1983), as in this case in Model 2, which shows a significant increment in the $F$ coefficient with an $R^{2}$ change $=.023(p<.05)$.

Therefore, the sign and the significance of the firm size variables and the interaction term support Hypothesis 1 regarding the positive effect of firm size on ambidexterity and Hypothesis 2 regarding the negative moderating effect of CIRs on the relationship between size and ambidexterity. We can also observe that CIRs do not influence ambidexterity because of the nonsignificant coefficient $(\beta=-0.091, p>.10)$.

To better interpret and test the moderating variable's effect, we plot the effect of size on ambidexterity depending on the CIR variable's different levels. Following Aiken and West (1991), we plot the CIR variable's high and low levels (one standard deviation higher and lower than the mean). Figure 2 illustrates the plot. Consistent with these expectations, when the CIR variable is at the lowest level (i.e., when firms do not have clear and consistent routines for environmental scanning and using information from competitive intelligence systems), the slope is positive, indicating a positive effect of size on ambidexterity. However, the slope becomes slightly negative when the CIR variable is at the highest level. Therefore, when CIR use is high, the positive effect of size on ambidexterity disappears, confirming Hypothesis 2.

To gain a deeper understanding of this moderating effect, we apply the Johnson-Neyman technique, which allows us to precisely define the regions in which the coefficient of the size variable is significantly positive or negative conditional on the different values of the CIR moderating variable (Preacher et al., 2007). Specifically, this technique tests the region of significance, indicating the range of the moderator variable within which the effect on the main variables is significantly different from zero.

The dotted lines in Figure 3 represent the confidence intervals and the interaction effect is significant when both are higher or lower than 0 (i.e., when the confidence interval does not include 0 ). The vertical dotted line represents the region's boundaries in which the interaction coefficient is significant at the 0.05 level.

In this case, for low CIR levels (i.e., levels below 0.2007), both lines of the confidence interval are higher than 0 , indicating a positive conditional effect of size on ambidexterity. As the CIR level increases, the conditional effect of size on ambidexterity decreases. When CIR achieves a certain value (0.2007), the effect of size on ambidexterity is no longer significant because the confidence interval includes 0 . This represents $61.16 \%$ of the firms in our sample, indicating that for high CIR levels, size does not determine firms' high capability to develop ambidextrous behaviors. Therefore, these results confirm Hypothesis 2, showing that when the CIR levels have medium to high values (higher than 0.2007 ), the effect of size on ambidexterity is not significant.

\section{Discussion}

Our study aims to analyze the unexplored role of CIRs as a moderating factor in the relationship between size and 


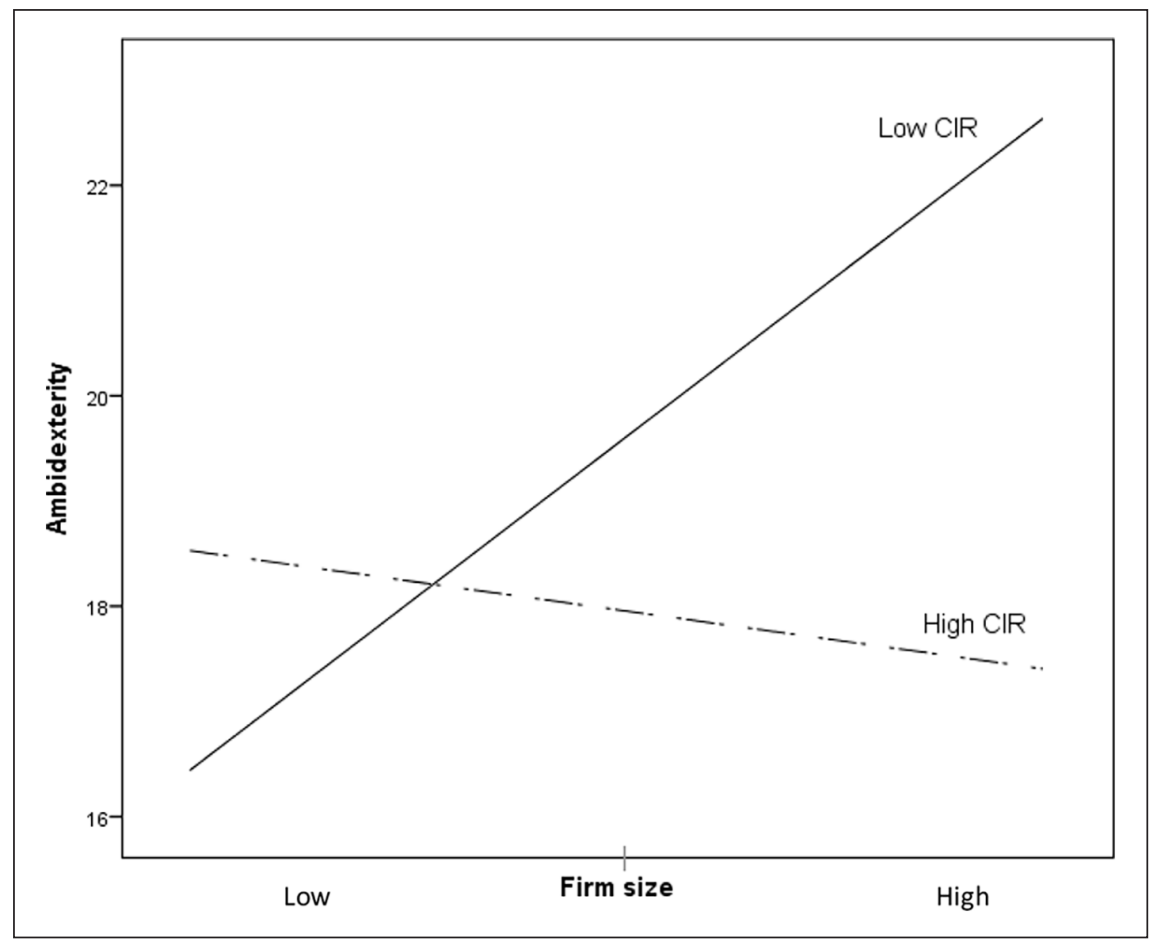

Figure 2. Interaction plot of CIR and firm size on ambidexterity. Note: $\mathrm{CIR}=$ competitive intelligence routine.

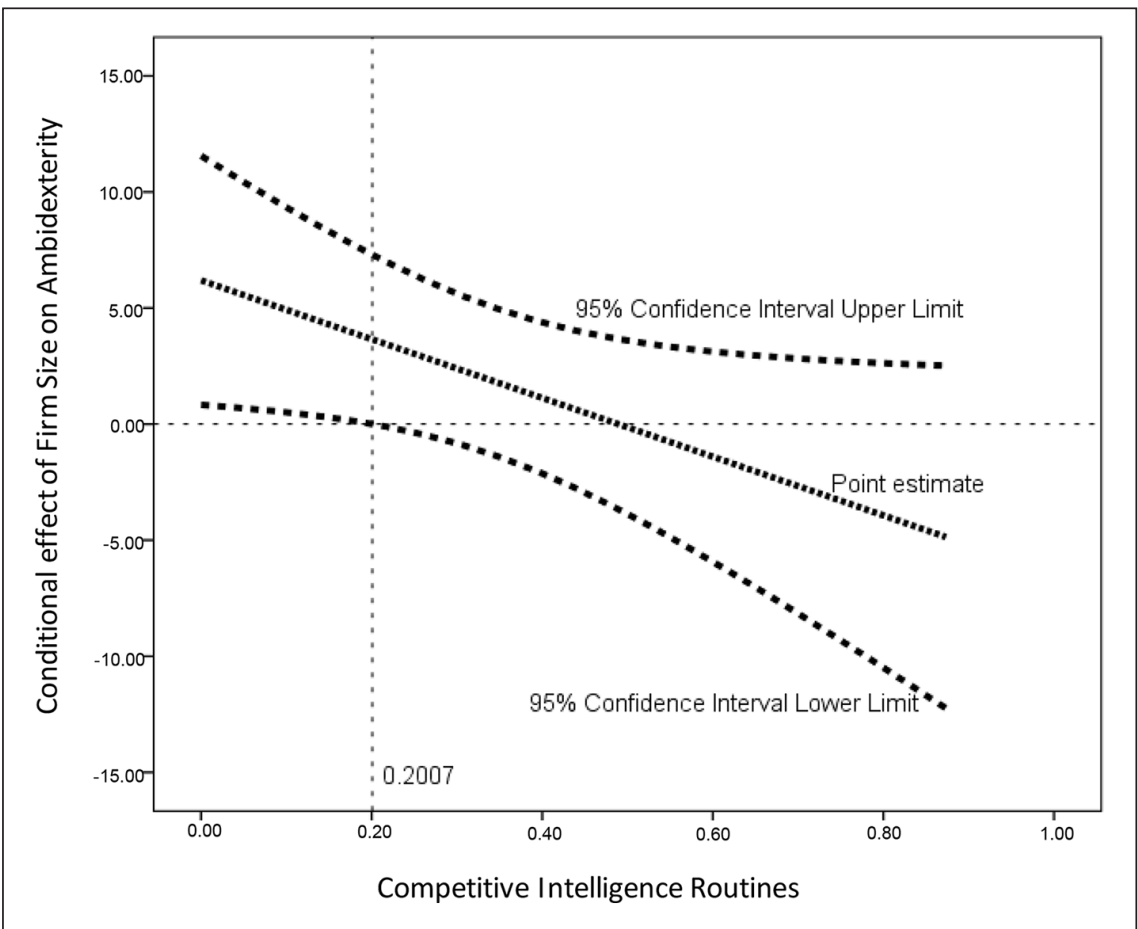

Figure 3. Coefficient of firm size on ambidexterity conditional on the moderating effect.

ambidexterity and shows that the favorable context provided by a larger organizational size to foster ambidexterity is no longer relevant when firms develop and incorporate CIRs in their strategic decision-making processes. CIRs allow firms to become aware of external trends and prompt them on the importance of pursuing ambidexterity. This conclusion is important for small and micro firms, which often lack resources and the possibility of dedicating 
separated units or structures to simultaneously conduct exploration and exploitation activities. Our results show that firms that consistently participate in competitive intelligence activities can leverage their organizational routines to better understand market trends and changes and incorporate this knowledge into their decision-making processes. Under these conditions, both smaller and larger firms do not have significant differences in their inclination to explore new capabilities, activities, and processes to adapt to new trends or exploit their existing knowledge to increase their efficiency and productivity.

The literature on ambidexterity proposes that firms that simultaneously explore and exploit knowledge achieve higher performance levels and that fostering ambidexterity is a significant challenge for firms that do not have slack resources or cannot dedicate specific units to pursue different (and frequently contradictory) efforts. Our findings show that having CIRs is a factor that moderates the influence of firm size on ambidexterity. In this sense, they imply that smaller firms can counterbalance their resource limitations by taking profits from organizational routines that facilitate the promotion of contextual ambidexterity. In this way, CIRs compensate for size constraints by providing small firms with an equivalent context to move toward ambidexterity. In other words, the development of CIR makes differences in organizational size among firms, not a decisive factor in explaining ambidexterity. Fourné et al. (2019) infer in their meta-analysis that the advantages and disadvantages of firms of different sizes compensate each other regarding ambidexterity. They do not find differences in the structural approach's benefits in achieving ambidexterity based on organizational size. This compensation effect could also explain the reduction in the size effect on ambidexterity in our results after taking into account the moderating effect of CIRs. That is, when organizations have a systematic scanning approach through CIRs, the size effect loses strength. The high availability of resources in larger firms maintains positive effects on ambidexterity. However, smaller firms with high flexibility and reduced inertial forces could also achieve ambidexterity by quickly and effectively allocating resources (Fourné et al., 2019) if they are aware of the necessity to develop ambidexterity given the awakening that CIRs produce.

Our results also show that a larger organizational size still creates a better context to foster ambidexterity, especially when the level of commitment with CIR is very low. The Johnson-Neyman analysis of the moderating effect of CIR on the relationship between size and ambidexterity shows that the effect of size on ambidexterity is positive and significant when CIR is very low. However, the effect of size disappears (becomes nonsignificant) when CIR achieves a minimum level.

However, our study is also useful for discussing whether the existence of CIR in a company is a direct antecedent of ambidexterity. Our results support the concept that scanning activities do not directly shape the company's ambidextrous capabilities, in line with previous studies (e.g., Zollo \& Winter, 2002). Rather, these activities act as a stimulus in developing responses that may be better adapted to environmental conditions. In this sense, CIRs do not directly affect ambidexterity. Firms with higher CIR levels (stronger commitment to dedicate resources and time to participate in competitive intelligence systems) will be more aware of environmental trends and the key success factors. They will make strategic decisions to attain a better market position.

In some cases, they may opt to exploit their current knowledge and capabilities. In other cases, they may focus on exploring new knowledge, applications, or opportunities. Other companies may simultaneously foster exploration and exploitation and pursue a more ambidextrous orientation. However, our research shows that small and micro firms may behave as ambidextrous as the larger ones in the presence of a minimum CIR level, indicating a moderating effect of CIR on the relationship between organizational size and ambidexterity.

\section{Conclusion}

This article contributes to the literature on ambidexterity by analyzing how the adoption of CIRs creates a context in which organizational size loses relevance in providing a context to foster ambidexterity in organizations. Companies that develop certain environmental scanning and analysis routines and integrate them into their strategic decisionmaking can achieve similar ambidexterity levels independent of their size. In this way, we contribute to the call to advance the analysis of contingencies in the ambidexterity study (Fourné et al., 2019). Our results refine the existing knowledge about the positive effect of size on ambidexterity (e.g., Cao et al., 2009) by introducing the moderating effect of CIRs. Without considering CIRs, a large size provides a better context in which to achieve higher ambidexterity. However, small firms can also pursue ambidextrous positions when they adopt specific routines that can compensate for some of the constraints and limitations related to the availability of resources or dedicated structures. Once small firms are aware of environmental trends and key success factors, they can be as ambidextrous as large firms and can use their flexibility (Alcalde-Heras et al., 2019; Veugelers, 1997) and low levels of inertia (Fourné et al., 2019) to pursue ambidexterity.

The present study also contributes to research on SMEs' strategy and competitiveness, given that we show how firms that develop CIRs can compensate for their size constraints and leverage their flexibility and agility to compete effectively. In addition, our results point out that the influence of size on ambidexterity is only relevant when CIR levels are very low, adding new insights for the call for 
further research on ambidexterity in SMEs (Prajogo et al., 2013; Soto-Acosta et al., 2018).

We also contribute to the competitive intelligence literature by highlighting it as an important factor, in line with the crucial role proposed by Erickson and Rothberg (2009) and, recently, Hunt and Madhavaram's (2020) requirement for firms' success. Scanning the environment is necessary for firms to be aware of the necessity to explore new knowledge, activities, or processes to trigger these firms' development and enable them to assess potential advantages or focus on exploiting existing knowledge. This study shows that CIRs are relevant for small firms despite their initial resistance to integrating these systems (Smith et al., 2010).

Our results also have stimulating implications. First, small company managers can better understand the advantages of overcoming the possible resistance to integrating systematic approaches to scanning the environment. Competitive intelligence systems and routines provide firms with a greater awareness of external trends and may facilitate a better assessment of the convenience of developing knowledge exploration or exploitation activities, or both simultaneously. Doing so could facilitate firms' realization of the necessity of rethinking their business models for long-term survival and provide a stimulus for reconfiguring current resources and capabilities. Given that large firms typically have better conditions for developing these scanning routines and can dedicate resources to promote ambidexterity, it is important to awaken small firms' orientation to understand environmental trends and use their flexibility to pursue ambidexterity. In this sense, it is encouraging to know that once small firms become aware of this importance by adopting environmental scanning and information-seeking routines via competitive intelligence systems, they can employ this knowledge in their decision-making processes and use their advantages in agility, flexibility, and adaptability to achieve similar ambidexterity levels as larger firms.

Our results also assert that governments and industrial institutions can boost CIR's enhancement in SMEs by promoting regional or sectorial competitive intelligence systems. Smaller firms face difficulties devoting resources to develop and integrate competitive intelligence, but the institutional stimulus could help them gain competitiveness. Our results in the furniture sector could enhance the promotion of these schemes in other industries.

This study has some limitations. First, the cross-sectional nature of the data makes it difficult to derive conclusions about the causality between variables, which requires a longitudinal sample to better analyze these effects. We attempt to minimize this problem by including firms' participation (CIR variable) in the panel during a long period (from 1999 to 2011) and measuring the dependent variable at the end of these periods. Second, we only infer that CIRs allow firms to gain a strong awareness of the importance of investing in developing ambidexterity but do not study how CIRs increase awareness and proactive attitudes. Future studies should compare whether high CIR levels are the main reason for changing these attitudes. Third, we focus our analysis on the furniture sector, limiting our results to other industries. However, as a highly fragmented, mature and nonmunificent industry, it may be a good proxy for other similar industries that are highly relevant in most national economies. This could imply avenues for further research on investigating the role of CIRs in other environments. Fourth, our context of analysis is mainly composed of SMEs. Our arguments propose that larger firms (i.e., medium-sized and large enterprises) with significant resources are better at absorbing the possible risks related to introducing complex systems, whereas smaller firms (i.e., micro and small companies) have more flexibility and adaptability. Further analysis is required using a larger sample that could include a similar percentage of larger firms in comparison with smaller ones to test whether the relationship between size and ambidexterity takes other paths, as for example a curvilinear one. Future studies can also examine how firms with different size characteristics benefit ambidexterity in the presence of CIRs.

Furthermore, scanning activities and routines are necessary to activate better processes; however, future research should investigate how organizations adapt their processes according to the information provided by competitive intelligence. Thus, analyzing the existence of a leader in organizations' change processes and how such a leader can lead the firm toward ambidexterity and success could be an interesting line of research. Despite these limitations, our research provides positive reasons to integrate environmental scanning routines in small firms to foster ambidexterity.

\section{Authors' note}

Authors appear in alphabetical order. Their contribution to this paper has been equal.

\section{Acknowledgements}

The authors appreciate the help of AIDIMME through the contribution of anonymized data of the firms participating in the Spanish Observatory of the Furniture Market between 1999 and 2011.

\section{Declaration of conflicting interests}

The author(s) declared no potential conflicts of interest with respect to the research, authorship, and/or publication of this article.

\section{Funding}

The author(s) disclosed receipt of the following financial support for the research, authorship, and/or publication of this article: The authors appreciate the financial help of the Spanish Ministry of Economy and Competitiveness (Research project ECO2016$80002-\mathrm{R}$ ) as well as the support provided by AIDIMME. 


\section{ORCID iD}

Alejandro Escribá-Esteve (iD https://orcid.org/0000-0001-50217935

\section{Note}

1. The companies included in the observatory belong to the following industries (Clasificación Nacional de Actividades Económicas [CNAE] codes in parentheses, which are the Spanish equivalent to U.S. Standard Industrial Classification [SIC] codes): wood treating (sawing and planting) (1610); manufacture of veneer and wood panels (1621); manufacture of assembled wooden floors (1622); manufacture of other wooden products (e.g., cork, straw, and plaiting materials) (1629); manufacture of paints, varnishes, and similar coatings (2030); manufacture of glues (2052); manufacture of locks and fittings (2572); manufacture of office and commercial furniture (3101); manufacture of kitchen furniture (3102); manufacture of mattresses (3103); and the retail trade of furniture, lighting appliances, and other articles of use in domestic or specialized establishments (4759).

\section{References}

Aguilar, F. J. (1967). Scanning the business environment. McGraw-Hill.

Ahuja, G., \& Lampert, C. M. (2001). Entrepreneurship in the large corporation: A longitudinal study of how established firms create breakthrough inventions. Strategic Management Journal, 22(6-7), 521-543. https://doi.org/10.1002/smj.176

Aiken, L. S., \& West, S. G. (1991). Multiple regression: Testing and interpreting interactions. SAGE.

Alcalde-Heras, H., Iturrioz-Landart, C., \& Aragon-Amonarriz, C. (2019). SME ambidexterity during economic recessions: The role of managerial external capabilities. Management Decision, 57(1), 21-40. https://doi.org/10.1108/md-03-2016-0170

Alexiev, A. S., Jansen, J. J. P., Van Den Bosch, F. A. J., \& Volberda, H. W. (2010). Top management team advice seeking and exploratory innovation: The moderating role of TMT heterogeneity. Journal of Management Studies, 47(7), 13431364. https://doi.org/10.1111/j.1467-6486.2010.00919.x

Alexiev, A. S., Volberda, H., Jansen, J., \& Van Den Bosch, F. (2020). Contextualizing senior executive advice seeking: The role of decision process comprehensiveness and empowerment climate. Organization Studies, 41(4), 471497. https://doi.org/10.1177/0170840619830128

Anderson, J. C., \& Gerbing, D. W. (1988). Structural equation modeling in practice-A review and recommended 2-step approach. Psychological Bulletin, 103(3), 411-423. https:// doi.org/10.1037/0033-2909.103.3.411

Andriopoulos, C., \& Lewis, M. W. (2009). Exploitationexploration tensions and organizational ambidexterity: Managing paradoxes of innovation. Organization Science, 20(4), 696-717. https://doi.org/10.1287/orsc.1080.0406

Atuahene-Gima, K. (2005). Resolving the capability-rigidity paradox in new product innovation. Journal of Marketing, 69(4), 61-83. https://doi.org/10.1509/jmkg.2005.69.4.61

Autio, E., Sapienza, H. J., \& Almeida, J. G. (2000). Effects of age at entry, knowledge intensity, and imitability on international growth. Academy of Management Journal, 43(5), 909-924. https://doi.org/10.2307/1556419
Barnett, W. P., Greve, H. R., \& Park, D. Y. (1994). An evolutionary model of organizational performance. Strategic Management Journal, 15, 11-28. https://doi.org/10.1002/ smj.4250150903

Barron, A., Hulten, P., \& Vanyushyn, V. (2015). Country-oforigin effects on managers' environmental scanning behaviours: Evidence from the political crisis in the Eurozone. Environment and Planning C: Government and Policy, 33(3), 601-619. https://doi.org/10.1068/c13176b

Bauer, M., \& Leker, J. (2013). Exploration and exploitation in product and process innovation in the chemical industry. $R$ \& D Management, 43(3), 196-212. https://doi.org/10.1111/ radm.12012

Belseley, D., Kuh, E., \& Welsch, R. (1980). Regression diagnostics: Identifying sources of influential observations and collinearity. John Wiley.

Benner, M. J., \& Tushman, M. L. (2003). Exploitation, exploration, and process management: The productivity dilemma revisited. Academy of Management Review, 28(2), 238256. https://doi.org/10.2307/30040711

Bergeron, P. (2000). Regional business intelligence: The view from Canada. Journal of Information Science, 26(3), 153160. https://doi.org/10.1177/016555150002600305

Bernhardt, D. C. (1994). I want it fast, factual, actionable-Tailoring competitive intelligence to executive needs. Long Range Planning, 27(1), 12-24. https://doi. org/10.1016/0024-6301(94)90003-5

Birkinshaw, J., \& Gupta, K. (2013). Clarifying the distinctive contribution of ambidexterity to the field of organization studies. Academy of Management Perspectives, 27(4), 287298. https://doi.org/10.5465/amp.2012.0167

Bourgeois, L. (1981). On the measurement of organizational slack. Academy of Management Review, 6(1), 29-39.

Boyd, B. K., \& Fulk, J. (1996). Executive scanning and perceived uncertainty: A multidimensional model. Journal of Management, 22(1), 1-21. https://doi.org/10.1177/ 014920639602200101

Brown, S. L., \& Eisenhardt, K. M. (1997). The art of continuous change: Linking complexity theory and timepaced evolution in relentlessly shifting organizations. Administrative Science Quarterly, 42(1), 1-34. https://doi. org/10.2307/2393807

Cantonnet, M. L., Aldasoro, J. C., \& Cilleruelo, E. (2015). Analysis of the competitive intelligence activities of small and mediumsized enterprises from the industrial sector. Human Factors and Ergonomics in Manufacturing \& Service Industries, 25(6), 646-658. https://doi.org/10.1002/hfm.20582

Cao, Q., Gedajlovic, E., \& Zhang, H. P. (2009). Unpacking organizational ambidexterity: Dimensions, contingencies, and synergistic effects. Organization Science, 20(4), 781796. https://doi.org/10.1287/orsc.1090.0426

Casado Salguero, G., Fernández Gámez, M. Á., Aldeanueva Fernández, I., \& Ruíz Palomo, D. (2019). Competitive intelligence and sustainable competitive advantage in the hotel industry. Sustainability, 11(6), 1597. https://doi. org/10.3390/su11061597

Chang, Y. Y., \& Hughes, M. (2012). Drivers of innovation ambidexterity in small- to medium-sized firms. European Management Journal, 30(1), 1-17. https://doi.org/10.1016/j. emj.2011.08.003 
Chen, M.-J. (1996). Competitor analysis and interfirm rivalry: Toward a theoretical integration. Academy of Management Review, 21(1), 100-134. https://doi.org/10.5465/amr.1996. 9602161567

Chen, M.-J., Su, K.-H., \& Tsai, W. (2007). Competitive tension: The awareness-motivation-capability perspective. Academy of Management Journal, 50(1), 101-118. https:// doi.org/10.5465/amj.2007.24162081

Cohen, J., \& Cohen, P. (1983). Applied multiple regression/ correlation analyses for the behavioral sciences (2nd ed.). Erlbaum.

Daft, R. L., Sormunen, J., \& Parks, D. (1988). Chief executive scanning, environmental characteristics, and company performance-An empirical study. Strategic Management Journal, 9(2), 123-139. https://doi.org/10.1002/smj.4250090204

Damanpour, F. (1991). Organizational innovation-A meta-analysis of determinants and moderators. Academy of Management Journal, 34(3), 555-590. https://doi.org/10.2307/256406

Danneels, E. (2008). Organizational antecedents of second-order competences. Strategic Management Journal, 29(5), 519543. https://doi.org/10.1002/smj.684

de Almeida, F. C., Lesca, H., \& Canton, A. W. P. (2016). Intrinsic motivation for knowledge sharing-Competitive intelligence process in a telecom company. Journal of Knowledge Management, 20(6), 1282-1301. https://doi.org/10.1108/ jkm-02-2016-0083

Duncan, R. (1976). The ambidextrous organization: Designing dual structures for innovation. In R. H. Killman, L. Pondy, \& D. Sleven (Eds.), The management of organization (pp. 167-188). Elsevier.

Erickson, G. S., \& Rothberg, H. N. (2009). Intellectual capital in business-to-business markets. Industrial Marketing Management, 38(2), 159-165. https://doi.org/10.1016/j. indmarman.2008.12.001

Floyd, S. W., \& Lane, P. J. (2000). Strategizing throughout the organization: Managing role conflict in strategic renewal. Academy of Management Review, 25(1), 154-177. https:// doi.org/10.2307/259268

Fornell, C., \& Larcker, D. F. (1981). Evaluating structural equation models with unobservable variables and measurement error. Journal of Marketing Research, 18(1), 39-50. https:// doi.org/10.2307/3151312

Fourné, S. P. L., Rosenbusch, N., Heyden, M. L. M., \& Jansen, J. J. P. (2019). Structural and contextual approaches to ambidexterity: A meta-analysis of organizational and environmental contingencies. European Management Journal, 37(5), 564-576. https://doi.org/10.1016/j.emj.2019.04.002

Ghobadian, A., \& Gallear, D. (1997). TQM and organization size. International Journal of Operations \& Production Management, 17(1-2), 121-163. https://doi. org/10.1108/01443579710158023

Gibson, C. B., \& Birkinshaw, J. (2004). The antecedents, consequences, and mediating role of organizational ambidexterity. Academy of Management Journal, 47(2), 209-226. https://doi.org/10.2307/20159573

Haase, H., \& Franco, M. (2011). Information sources for environmental scanning: Do industry and firm size matter? Management Decision, 49(9-10), 1642-1657. https://doi. org/10.1108/00251741111183807

Hair, J. F., Tatham, R. L., Anderson, R. E., \& Black, W. (2006). Multivariate data analysis (6th ed.). Pearson Prentice Hall.
Hambrick, D. C. (1982). Environmental scanning and organizational strategy. Strategic Management Journal, 3(2), 159 174. https://doi.org/10.1002/smj.4250030207

He, Z. L., \& Wong, P. K. (2004). Exploration vs. exploitation: An empirical test of the ambidexterity hypothesis. Organization Science, 15(4), 481-494. https://doi. org/10.1287/orsc. 1040.0078

Helfat, C. E., \& Peteraf, M. A. (2015). Managerial cognitive capabilities and the microfoundations of dynamic capabilities. Strategic Management Journal, 36(6), 831-850. https://doi.org/10.1002/smj.2247

Hill, S. A., \& Birkinshaw, J. (2014). Ambidexterity and survival in corporate venture units. Journal of Management, 40(7), 1899-1931. https://doi.org/10.1177/0149206312445925

Huff, J. O., Huff, A. S., \& Thomas, H. (1992). Strategic renewal and the interaction of cumulative stress and inertia. Strategic Management Journal, 13, 55-75. https://doi.org/10.1002/ smj.4250131006

Hughes, P., Hughes, M., Stokes, P., Lee, H., Rodgers, P., \& Degbey, W. Y. (2020). Micro-foundations of organizational ambidexterity in the context of cross-border mergers and acquisitions. Technological Forecasting and Social Change, 153, 119932. https://doi.org/10.1016/j.techfore.2020.119932

Hunt, S., \& Madhavaram, S. (2020). Adaptive marketing capabilities, dynamic capabilities, and renewal competences: The "outside vs. inside" and "static vs. dynamic" controversies in strategy. Industrial Marketing Management, 89(20), 129-139. https://doi.org/10.1016/j.indmarman.2019.07.004

Instituto Nacional de Estadística. (2021). Central business register. CBR data. Retrieved September 15, 2021, from https://www.ine.es/dyngs/INEbase/en/operacion.htm?c= Estadistica_C\&cid $=1254736160707 \&$ menu $=u l t i D a t o s \&$ idp $=1254735576550$

Jansen, J. J. P., George, G., Van den Bosch, F. A. J., \& Volberda, H. W. (2008). Senior team attributes and organizational ambidexterity: The moderating role of transformational leadership. Journal of Management Studies, 45(5), 9821007. https://doi.org/10.1111/j.1467-6486.2008.00775.x

Jansen, J. J. P., Simsek, Z., \& Cao, Q. (2012). Ambidexterity and performance in multiunit contexts: Cross-level moderating effects of structural and resource attributes. Strategic Management Journal, 33(11), 1286-1303. https://doi. org/10.1002/smj.1977

Jansen, J. J. P., Tempelaar, M. P., van den Bosch, F. A. J., \& Volberda, H. W. (2009). Structural differentiation and ambidexterity: The mediating role of integration mechanisms. Organization Science, 20(4), 797-811. https://doi. org/10.1287/orsc.1080.0415

Jansen, J. J. P., Van den Bosch, F. A. J., \& Volberda, H. W. (2006). Exploratory innovation, exploitative innovation, and performance: Effects of organizational antecedents and environmental moderators. Management Science, 52(11), 1661-1674. https://doi.org/10.1287/mnsc. 1060.0576

Jiménez-Jiménez, D., Martínez-Costa, M., \& Sánchez Rodriguez, C. (2019). The mediating role of supply chain collaboration on the relationship between information technology and innovation. Journal of Knowledge Management, 23(3), 548-567. https://doi.org/10.1108/JKM-01-2018-0019

Kammerlander, N., Patzelt, H., Behrens, J., \& Röhm, C. (2020). Organizational ambidexterity in family-managed firms: The role of family involvement in top management. 
Family Business Review, 33(4), 393-423. https://doi. org/10.1177/0894486520961645

Koryak, O., Lockett, A., Hayton, J., Nicolaou, N., \& Mole, K. (2018). Disentangling the antecedents of ambidexterity: Exploration and exploitation. Research Policy, 47(2), 413427. https://doi.org/10.1016/j.respol.2017.12.003

Lavie, D., Stettner, U., \& Tushman, M. L. (2010). Exploration and exploitation within and across organizations. Academy of Management Annals, 4, 109-155. https://doi. org/10.1080/19416521003691287

Leonard-Barton, D. (1992). Core capabilities and core rigidities-A paradox in managing new development. Strategic Management Journal, 13, 111-125. https://doi.org/10.1002/ smj.4250131009

Lerner, J. (2006). The new financial thing: The origins of financial innovations. Journal of Financial Economics, 79(2), 223-255. https://doi.org/10.1016/j.jfineco.2005.01.004

Levinthal, D. A., \& March, J. G. (1993). The myopia of learning. Strategic Management Journal, 14, 95-112. https://doi. org/10.1002/smj.4250141009

Li, Y. H., \& Huang, J. W. (2012). Ambidexterity's mediating impact on product development proficiency and new product performance. Industrial Marketing Management, 41(7), 1125-1132. https://doi.org/10.1016/j.indmarman.2012.05.002

Liao, J., Welsch, H., \& Stoica, M. (2008). Environmental turbulence and scanning behavior: The moderating effects of organizational maturity. Journal of Small Business Strategy, 19(1), 17-34.

Limaj, E., \& Bernroider, E. W. (2019). The roles of absorptive capacity and cultural balance for exploratory and exploitative innovation in SMEs. Journal of Business Research, 94, 137-153. https://doi.org/10.1016/j.jbusres.2017.10.052

Lindgreen, A., \& Di Benedetto, C. (2018). Continuous improvement at industrial marketing management: Suggestions from the Editorial Review Board. Industrial Marketing Management, 71, 1-4. https://doi.org/10.1016/j.indmarman.2018.04.017

Lubatkin, M. H., Simsek, Z., Ling, Y., \& Veiga, J. F. (2006). Ambidexterity and performance in small- to medium-sized firms: The pivotal role of top management team behavioral integration. Journal of Management, 32(5), 646-672. https://doi.org/10.1177/0149206306290712

March, J. G. (1991). Exploration and exploitation in organizational learning. Organization Science, 2(1), 71-87. https:// doi.org/10.1287/orsc.2.1.71

Matthews, C. H., \& Scott, S. G. (1995). Uncertainty and planning in small and entrepreneurial firms-An empirical assessment. Journal of Small Business Management, 33(4), 34-52.

McAdam, R., Moffett, S., Hazlett, S. A., \& Shevlin, M. (2010). Developing a model of innovation implementation for UK SMEs: A path analysis and explanatory case analysis. International Small Business Journal: Researching Entrepreneurship, 28(3), 195-214. https://doi. org/10.1177/0266242609360610

McGrath, R. G. (2001). Exploratory learning, innovative capacity, and managerial oversight. Academy of Management Journal, 44(1), 118-131. https://doi.org/10.2307/3069340

Menguc, B., \& Auh, S. (2008). The asymmetric moderating role of market orientation on the ambidexterity-firm performance relationship for prospectors and defenders.
Industrial Marketing Management, 37(4), 455-470. https:// doi.org/10.1016/j.indmarman.2007.05.002

Morgan, R. E., \& Berthon, P. (2008). Market orientation, generative learning, innovation strategy and business performance inter-relationships in bioscience firms. Journal of Management Studies, 45(8), 1329-1353. https://doi. org/10.1111/j.1467-6486.2008.00778.x

Muñoz-Cañavate, A., \& Alves-Albero, P. (2017). Competitive intelligence in Spain: A study of a sample of firms. Business Information Review, 34(4), 194-204. https://doi. org/10.1177/0266382117735982

Navarro, J. (2012). La inteligencia competitiva y la innovación estratégica: la prospectiva como fuente de creatividad estratégica [Competitive intelligence and strategic innovation: Prospective as a source of strategic creativity]. In M. Guilló \& E. Bas (Eds.), Prospectiva e innovación [Prospective and innovation] (Vol. 2, pp. 259-288). Plaza y Valdés. http:// digital.casalini.it/9788416032655

Navarro, J., Hayward, P., \& Voros, J. (2008). How to solve a wicked problem? Furniture foresight case study. Foresight, 10(2), 11-29.https://doi.org/10.1108/14636680810869653

Neirotti, P., \& Paolucci, E. (2011). Assessing the importance of industry in the adoption and assimilation of IT: Evidence from Italian enterprises. Information \& Management, 48(7), 249-259. https://doi.org/10.1016/j.im.2011.06.004

Olsen, N. V., \& Sallis, J. (2006). Market scanning for new service development. European Journal of Marketing, 40(5-6), 466-484. https://doi.org/10.1108/03090560610657796

O'Reilly, C. A., \& Tushman, M. L. (2004). The ambidextrous organisation. Harvard Business Review, 82(4), 74-83.

O’Reilly, C. A., \& Tushman, M. L. (2013). Organizational ambidexterity: Past, present, and future. Academy of Management Perspectives, 27(4), 324-338. https://doi.org/10.5465/ amp.2013.0025

Paliokaite, A., \& Pacesa, N. (2015). The relationship between organisational foresight and organisational ambidexterity. Technological Forecasting and Social Change, 101, 165181. https://doi.org/10.1016/j.techfore.2014.03.004

Peteraf, M. A., \& Bergen, M. E. (2003). Scanning dynamic competitive landscapes: A market-based and resource-based framework. Strategic Management Journal, 24(10), 10271041. https://doi.org/10.1002/smj.325

Pfeffer, J., \& Salancik, G. R. (1978). The external control of organizations: A resource dependence perspective. Harper \& Row.

Placer-Maruri, E., Pérez-González, D., \& Soto-Acosta, P. (2016). Effects of the use of competitive intelligence in industrial SMEs. Intangible Capital, 12(4), 923-941. https://doi. org/10.3926/ic. 750

Posch, A., \& Garaus, C. (2019). Boon or curse? A contingent view on the relationship between strategic planning and organizational ambidexterity. Long Range Planning, 53(6), 101878. https://doi.org/10.1016/j.lrp.2019.03.004

Prajogo, D. I., McDermott, C. M., \& McDermott, M. A. (2013). Innovation orientations and their effects on business performance: Contrasting small- and medium-sized service firms. $R \& D$ Management, 43(5), 486-500. https://doi. org/10.1111/radm.12027

Preacher, K. J., Rucker, D. D., \& Hayes, A. F. (2007). Addressing moderated mediation hypotheses: Theory, methods, and prescriptions. Multivariate Behavioral Research, 42(1), 185-227. https://doi.org/10.1080/00273170701341316 
Priem, R. L., Rasheed, A. M. A., \& Kotulic, A. G. (1995). Rationality in strategic decision-processes, environmental dynamism and firm performance. Journal of Management, 21(5), 913-929. https://doi.org/10.1016/0149-2063(95)90047-0

Qiu, T. (2008). Scanning for competitive intelligence: A managerial perspective. European Journal of Marketing, 42(7-8), 814-835. https://doi.org/10.1108/03090560810877178

Raisch, S., \& Birkinshaw, J. (2008). Organizational ambidexterity: Antecedents, outcomes, and moderators. Journal of Management, 34(3), 375-409. https://doi.org/10.1177/ 0149206308316058

Raisch, S., Birkinshaw, J., Probst, G., \& Tushman, M. L. (2009). Organizational ambidexterity: Balancing exploitation and exploration for sustained performance. Organization Science, 20(4), 685-695. https://doi.org/10.1287/orsc.1090.0428

Ramachandran, I., Lengnick-Hall, C. A., \& Badrinarayanan, V. (2019). Enabling and leveraging ambidexterity: Influence of strategic orientations and knowledge stock. Journal of Knowledge Management, 23(6), 1136-1156. https://doi. org/10.1108/jkm-11-2018-0688

Revilla, E., \& Rodriguez-Prado, B. (2018). Bulding ambidexterity through creativity mechanisms: Contextual drivers of innovation success. Research Policy, 47(9), 1611-1625. https://doi.org/10.1016/j.respol.2018.05.009

Rialti, R., Zollo, L., Ferraris, A., \& Alon, I. (2019). Big data analytics capabilities and performance: Evidence from a moderated multi-mediation model. Technological Forecasting and Social Change, 149, 119781. https://doi.org/10.1016/j. techfore.2019.119781

Ridge, J. W., Kern, D., \& White, M. A. (2014). The influence of managerial myopia on firm strategy. Management Decision, 52(3), 602-623. https://doi.org/10.1108/md-01-2013-0037

Robins, J. A., \& Wiersema, M. F. (2003). The measurement of corporate portfolio strategy: Analysis of the content validity of related diversification indexes. Strategic Management Journal, 24(1), 39-59. https://doi.org/10.1002/smj.282

Rohrbeck, R., \& Gemunden, H. G. (2011). Corporate foresight: Its three roles in enhancing the innovation capacity of a firm. Technological Forecasting and Social Change, 78(2), 231-243. https://doi.org/10.1016/j.techfore.2010.06.019

Shu, C., Zhao, M., Liu, J., \& Lindsay, W. (2020). Why firms go green and how green impacts financial and innovation performance differently: An awareness-motivation-capability perspective. Asia Pacific Journal of Management, 37, 795-821. https://doi.org/10.1007/s10490-018-9630-8

Siggelkow, N., \& Levinthal, D. A. (2003). Temporarily divide to conquer: Centralized, decentralized, and reintegrated organizational approaches to exploration and adaptation. Organization Science, 14(6), 650-669. https://doi. org/10.1287/orsc.14.6.650.24840

Siggelkow, N., \& Rivkin, J. W. (2006). When exploration backfires: Unintended consequences of multilevel organizational search. Academy of Management Journal, 49(4), 779-795. https://doi.org/10.5465/amj.2006.22083053

Sirmon, D. G., Hitt, M. A., \& Ireland, R. D. (2007). Managing firm resources in dynamic environments to create value: Looking inside the black box. Academy of Management Review, 32(1), 273-292. https://doi.org/10.5465/amr.2007.23466005

Smith, J. R., \& Kossou, L. (2008). The emergence and uniqueness of competitive intelligence in France. Journal of Competitive Intelligence and Management, 4(3), 63-85.
Smith, J. R., Wright, S., \& Pickton, D. (2010). Competitive intelligence programmes for SMEs in France: Evidence of changing attitudes. Journal of Strategic Marketing, 18(7), 523-536. https://doi.org/10.1080/0965254x.2010.529154

Soto-Acosta, P., Popa, S., \& Martinez-Conesa, I. (2018). Information technology, knowledge management and environmental dynamism as drivers of innovation ambidexterity: A study in SMEs. Journal of Knowledge Management, 22(4), 824-849. https://doi.org/10.1108/jkm-10-2017-0448

Tang, T. W. (2016). Making innovation happen through building social capital and scanning environment. International Journal of Hospitality Management, 56, 56-65. https://doi. org/10.1016/j.ijhm.2016.04.002

Teece, D. J. (2007). Explicating dynamic capabilities: The nature and microfoundations of (sustainable) enterprise performance. Strategic Management Journal, 28(13), 1319-1350. https://doi.org/10.1002/smj.640

Tushman, M. L., \& O’Reilly, C. A. (1996). Ambidextrous organizations: Managing evolutionary and revolutionary change. California Management Review, 38(4), 8-29. https://doi. org/10.2307/41165852

Tushman, M. L., \& Romanelli, E. (1985). Organizational evolution: A metamorphosis model of convergence and reorientation. In L. L. Cummings \& B. M. Staw (Eds.), Research in organizational behavior (Vol. 7, pp. 171-122). JAI Press.

Veugelers, R. (1997). Internal R\&D expenditures and external technology sourcing. Research Policy, 26(3), 303-315. https://doi.org/10.1016/s0048-7333(97)00019-x

Voss, G. B., \& Voss, Z. G. (2013). Strategic ambidexterity in small and medium-sized enterprises: Implementing exploration and exploitation in product and market domains. Organization Science, 24(5), 1459-1477. https://doi. org/10.1287/orsc. 1120.0790

Wood, M. (2001). Marketing information systems in tourism and hospitality small- and medium-sized enterprises: A study of internet for market intelligence. International Journal of Tourism Research, 3(4), 283-299. https://doi.org/10.1002/jtr.315

Wuyts, S., Dutta, S., \& Stremersch, S.(2004). Portfolios of interfirm agreements in technology-intensive markets: Consequences for innovation and profitability. Journal of Marketing, 68(2), 88-100. https://doi.org/10.1509/jmkg.68.2.88.27787

Yang, S.-M., Fang, S.-C., Fang, S.-R., \& Chou, C.-H. (2014). Knowledge exchange and knowledge protection in interorganizational learning: The ambidexterity perspective. Industrial Marketing Management, 43(2), 346-358. https:// doi.org/10.1016/j.indmarman.2013.11.007

Yasai-Ardekani, M., \& Nystrom, P. C. (1996). Designs for environmental scanning systems: Tests of a contingency theory. Management Science, 42(2), 187-204. https://doi. org/10.1287/mnsc.42.2.187

Zhang, Y., \& Han, Y.-L. (2019). Paradoxical leader behavior in longterm corporate development: Antecedents and consequences. Organizational Behavior and Human Decision Processes, 155, 42-54. https://doi.org/10.1016/j.obhdp.2019.03.007

Zinkhan, G. M., \& Gelb, B. D. (1985). Competitive intelligence practices of industrial marketers. Industrial Marketing Management, 14(4), 269-275. https://doi.org/10.1016/00198501(85)90019-7

Zollo, M., \& Winter, S. G. (2002). Deliberate learning and the evolution of dynamic capabilities. Organization Science, 13(3), 339-351. https://doi.org/10.1287/orsc.13.3.339.2780 